\title{
STUDY OF CLINICAL PROFILE AND RISK FACTORS OF PNEUMONIA (CAP)
}

\author{
G. Vasavi Latha1, N. Ravi Kumar², P. Suresh Kumar ${ }^{3}$ \\ ${ }^{1}$ Associate Professor, Department of General Medicine, Andhra Medical College, Visakhapatnam. \\ ${ }^{2}$ Senior Resident, Department of General Medicine, Andhra Medical College, Visakhapatnam. \\ 3Junior Resident, Department of General Medicine, Andhra Medical College, Visakhapatnam.
}

\begin{tabular}{l}
\hline ABSTRACT \\
BACKGROUND \\
Community-acquired pneumonia (CAP), the most common type of pneumonia is one of the commonest infectious diseases and is \\
an important cause of mortality and morbidity in all age groups worldwide. Identifying people at risk for this infection aids in \\
appropriate treatment. Hence, there is a need for a study to know the clinical profile and risk factors of pneumonia (CAP). \\
Aim- To study the clinical profile and risk factors of pneumonia (CAP).
\end{tabular}

\section{MATERIALS AND METHODS}

50 patients who were admitted with pneumonia over a period of 7 months from 1 ${ }^{\text {st }}$ January 2017 to $31^{\text {st }}$ July 2017 in King George Hospital, Visakhapatnam were studied retrospectively.

\section{RESULTS}

In this study, majority of cases are males contributing 60\%. CAP is commonly seen in the age group of 51-60 years (26\%). The study shows that in young patients (age up to 50 years) cough with expectoration (34\%) was the most common clinical feature followed by fever (32\%) and breathlessness (22\%), and among old patients (age above 50 years) fever (58\%) was the most common clinical feature followed by cough with expectoration (40\%) and breathlessness (22\%). Pedal oedema, altered sensorium were present each as $4 \%$ but the former was seen in younger group and later was in older group. Among male patients smoking $(56 \%)$ was the most common risk factor followed by alcohol (40\%) and among female patients preceding diabetes (13\%) was the most common risk factor. In the present study, the radiological finding (consolidation) was more common on right side constituting about $56 \%$ of the cases followed by left side $(28 \%)$ and bilateral involvement in $16 \%$ cases. Right lower lobe involvement is more common in this study. Complications (20\%) were more common in males and above 50 years.

\section{CONCLUSION}

World Health Organization's (WHO) global burden of disease study estimated that lower respiratory tract infections (LRTIs), which include CAP, were 429.2 million. Commonly affected age group is 51-60 years which is the golden period in one's life. Patients, particularly elderly and debilitated having risk factors, should be instructed to seek prompt medical care during the early stages of dyspnoea or fever to prevent complications. Modifiable risk factors should be strictly corrected especially in those who also have fixed risk factors. Identification and determining the clinical patterns and risk factors of Pneumonia (CAP) helps in adoption of regionally optimised diagnostic and therapeutic approach.

\section{KEYWORDS}

Pneumonia (CAP), Clinical Features, Risk Factors, Prevention of Complications.

HOW TO CITE THIS ARTICLE: Latha GV, Kumar NR, Kumar PS. Study of clinical profile and risk factors of pneumonia (CAP). J. Evolution Med. Dent. Sci. 2017;6(89):6179-6183, DOI: 10.14260/jemds/2017/1343

\section{BACKGROUND}

World Health Organization's (WHO) global burden of disease study estimated that lower respiratory tract infections (LRTIs), which include CAP, were 429.2 million. It is also estimated deaths per 100,000 population in 2004 due to LRTI in India was 89.5. ${ }^{1}$ Community-acquired pneumonia (CAP) refers to pneumonia acquired outside of hospitals or extended-care facilities. CAP, the most common type of pneumonia is a spectrum of diseases ranging from a simple febrile respiratory infection to a severe and fulminating

'Financial or Other Competing Interest': None.

Submission 18-09-2017, Peer Review 26-10-2017,

Acceptance 02-11-2017, Published 13-11-2017.

Corresponding Author:

Dr. G. Vasavi Latha,

W/o. CH. Avatharamu Naidu,

Type 5/5, Port Quarters,

Maharanipeta,

Visakhapatnam-530002, Andhra Pradesh.

E-mail: doctorgvlatha@gmail.com

DOI: $10.14260 /$ jemds $/ 2017 / 1343$

(c) $\left(\right.$ ) ()$_{\mathrm{BY}}$ illness leading to death. Its causes include bacteria, viruses, fungi and parasites. $^{2}$ CAP is diagnosed by assessing symptoms, making a physical examination and on x-ray findings. Worldwide a number of guidelines have been published, describing the optimal treatment of patients with CAP, with the aim of improving patient outcomes. Hospitalised patients have an average mortality rate of 12 percent, with the rate rising to 40 percent for patients with bloodstream infections or requiring intensive care. ${ }^{3}$

Risk factors include other lung diseases such as cystic fibrosis, COPD, and asthma, diabetes, heart failure, history of smoking, poor ability to cough such as following a stroke, or a weak immune system. ${ }^{4}$ Most of these risk factors are associated with an impairment of the efficacy of host immune defence. Many of these risk factors are also associated with a greater mortality risk. ${ }^{5}$

At risk patients require vaccination for Pneumococcal and influenza infections, and smoking cessation programs to decrease the incidence and severity of CAP. 
Aim

To study the clinical profile and risk factors of Pneumonia (CAP).

\section{MATERIALS AND METHODS}

Sample was collected retrospectively from cases admitted in King George Hospital, Visakhapatnam with pneumonia (CAP) over a period of 7 months' time (1 ${ }^{\text {st }}$ January 2017 to $31^{\text {st }}$ July 2017). Detailed history taking and clinical examination were done. Cases were analysed for various lab investigations, $\mathrm{x}$ ray chest, sputum examination. CT chest which was done in required cases also noted. Age, sex, duration of stay, severity, complications and mortality were noted.

\section{Inclusion Criteria}

Both sexes aged more than 12 years who were admitted in medical wards with clinical diagnosis of pneumonia and were radiologically confirmed are included.

\section{Exclusion Criteria}

- Both sexes aged less than 12 years.

- Pregnant.

- Only clinical or radiological diagnosis was excluded.

\begin{tabular}{|c|c|}
\hline Gender & Incidence \\
\hline Male & $30(60 \%)$ \\
\hline Female & $20(40 \%)$ \\
\hline Total & 50 \\
\hline Table 1. Distribution of Cases According to Gender \\
\hline
\end{tabular}

\section{GENDER WISE DISTRIBUTION}

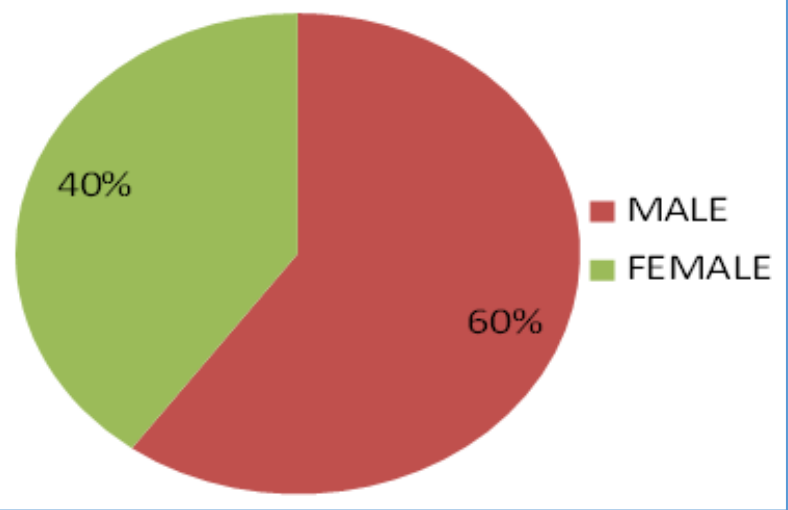

Figure 1. Distribution of Cases According to Gender

In this study, the incidence of Pneumonia was more common in males (60\%) as compared to females (40\%). (Table 1).

\begin{tabular}{|c|c|c|c|}
\hline Age (years) & Males & Females & Total \\
\hline $11-20$ & 3 & 1 & $\mathbf{4}(\mathbf{8 \% )}$ \\
\hline $21-30$ & 6 & 3 & $\mathbf{9 ( 1 8 \% )}$ \\
\hline $31-40$ & 0 & 3 & $\mathbf{3}(\mathbf{6 \% )}$ \\
\hline $41-50$ & 7 & 4 & $\mathbf{1 1}(\mathbf{2 2 \% )}$ \\
\hline $51-60$ & 8 & 5 & $\mathbf{1 3}(\mathbf{2 6 \% )}$ \\
\hline $61-70$ & 4 & 3 & $\mathbf{7 ( 1 4 \% )}$ \\
\hline $71-80$ & 2 & 1 & $\mathbf{3}(\mathbf{6 \% )}$ \\
\hline Total & 30 & 20 & $\mathbf{5 0}$ \\
\hline
\end{tabular}

Table 2. Distribution of Cases According to Age and Gender

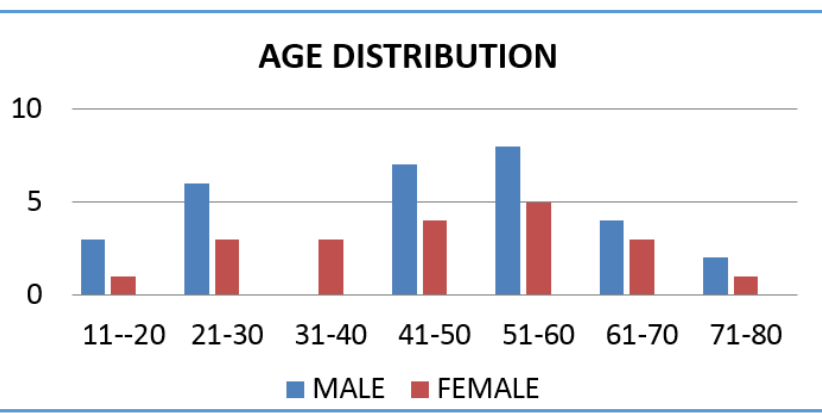

Figure 2. Distribution of Cases According to Age and Gender

In this present study, the highest incidence was found in the age group 51-60 years (26\%) followed by $41-50$ years $(22 \%)$ then followed by $21-30$ years (18\%).

The present study reveals that age up to 50 years constituted $54 \%$ and above 50 years constituted $46 \%$. Both males and females are more affected during the age 50 years or less. (Table 2).

\begin{tabular}{|c|c|c|c|c|c|}
\hline \multirow[b]{2}{*}{$\begin{array}{c}\text { Clinical } \\
\text { Features }\end{array}$} & Age & & Gender & & \multirow[b]{2}{*}{$\begin{array}{c}\text { Total } \\
(n=50)\end{array}$} \\
\hline & $\begin{array}{c}<\text { <50 } \\
\text { Years }\end{array}$ & $\begin{array}{c}>50 \\
\text { Years }\end{array}$ & $\begin{array}{c}\text { Male } \\
(n=30)\end{array}$ & \begin{tabular}{|l|} 
Female \\
$(n=20)$
\end{tabular} & \\
\hline Fever & $\begin{array}{c}16 \\
(32 \%)\end{array}$ & $\begin{array}{c}29 \\
(58 \%)\end{array}$ & $28(93 \%)$ & $\begin{array}{c}17 \\
(85 \%) \\
\end{array}$ & $\begin{array}{c}45 \\
(90 \%) \\
\end{array}$ \\
\hline $\begin{array}{l}\text { Coug } \\
\text { expec }\end{array}$ & $\begin{array}{c}17 \\
(34 \%)\end{array}$ & $\begin{array}{c}20 \\
(40 \%)\end{array}$ & $22(73 \%)$ & $\begin{array}{c}15 \\
(75 \%)\end{array}$ & $\begin{array}{c}37 \\
(74 \%) \\
\end{array}$ \\
\hline Breathlessness & $\begin{array}{c}11 \\
(22 \%)\end{array}$ & $\begin{array}{c}11 \\
(22 \%) \\
\end{array}$ & $15(50 \%)$ & $\begin{array}{c}7 \\
(35 \%) \\
\end{array}$ & \begin{tabular}{|c|}
22 \\
$(44 \%)$ \\
\end{tabular} \\
\hline Che & $\begin{array}{c}4 \\
(8 \%) \\
\end{array}$ & $\begin{array}{c}6 \\
(12 \%) \\
\end{array}$ & $\begin{array}{c}5 \\
(16 \%) \\
\end{array}$ & $\begin{array}{c}5 \\
(25 \%) \\
\end{array}$ & $\begin{array}{c}10 \\
(20 \%) \\
\end{array}$ \\
\hline Pedal oedema & $\begin{array}{c}2 \\
(4 \%) \\
\end{array}$ & 0 & $\begin{array}{c}1 \\
(3 \%)\end{array}$ & $\begin{array}{c}1 \\
(5 \%)\end{array}$ & $\begin{array}{c}2 \\
(4 \%)\end{array}$ \\
\hline Haem & $\begin{array}{c}1 \\
(2 \%)\end{array}$ & $\begin{array}{c}1 \\
(2 \%)\end{array}$ & $\begin{array}{c}2 \\
(6 \%)\end{array}$ & 0 & $\begin{array}{c}2 \\
(4 \%)\end{array}$ \\
\hline $\begin{array}{c}\text { Altered } \\
\text { sensorium }\end{array}$ & 0 & $\begin{array}{c}2 \\
(4 \%)\end{array}$ & $\begin{array}{c}1 \\
(3 \%)\end{array}$ & $\begin{array}{c}1 \\
(5 \%)\end{array}$ & $\begin{array}{c}2 \\
(4 \%)\end{array}$ \\
\hline \multicolumn{6}{|c|}{$\begin{array}{l}\text { Table 3. Distribution of Clinical Features According to Age } \\
\text { and Gender }\end{array}$} \\
\hline
\end{tabular}

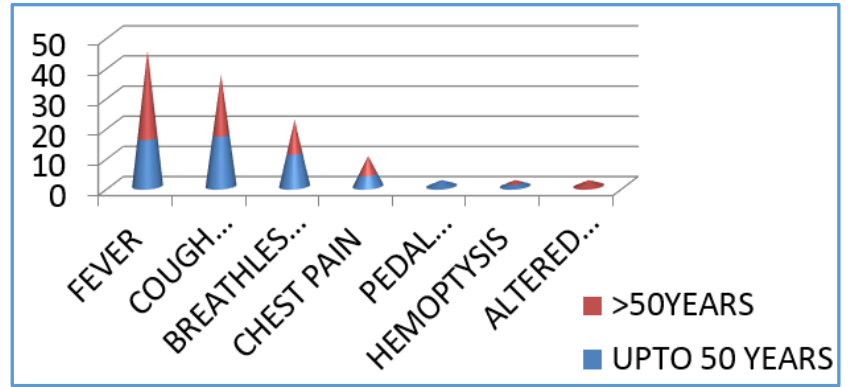

Figure 3. Distribution of Clinical Features According to Age

The table 3 shows that fever $(90 \%)$ was the most common symptom followed by cough $(74 \%)$. The study shows that in young patients (age is $<50$ years) cough with expectoration $(34 \%)$ was the most common clinical feature followed by fever (32\%) and breathlessness (22\%) and among old patients (age is $>50$ years) fever (58\%) was the most common clinical feature followed by cough with expectoration $(40 \%)$ and breathlessness (22\%). Pedal oedema and altered sensorium were present each as $4 \%$ but the former was seen in younger group and later in older group. 


\begin{tabular}{|c|c|c|c|c|c|}
\hline $\begin{array}{c}\text { Risk } \\
\text { Factor }\end{array}$ & $\begin{array}{c}\text { Age <_50 } \\
\text { Years }\end{array}$ & $\begin{array}{c}>50 \\
\text { Years }\end{array}$ & $\begin{array}{c}\text { Male } \\
(\mathbf{n = 3 0})\end{array}$ & $\begin{array}{c}\text { Female } \\
(\mathbf{n = 2 0})\end{array}$ & $\begin{array}{c}\text { Total } \\
(\mathbf{n = 5 0 )}\end{array}$ \\
\hline Diabetes & $\begin{array}{c}3 \\
(6 \%)\end{array}$ & $\begin{array}{c}5 \\
(10 \%)\end{array}$ & $\begin{array}{c}4 \\
(13 \%)\end{array}$ & $\begin{array}{c}4 \\
(13 \%)\end{array}$ & $\begin{array}{c}8 \\
(16 \%)\end{array}$ \\
\hline Alcohol & 4 & 8 & 12 & 0 & $12(24 \%)$ \\
$(8 \%)$ & $(16 \%)$ & $(40 \%)$ & & 4 \\
\hline $\begin{array}{c}\text { Lung } \\
\text { pathology }\end{array}$ & 1 & 3 & 3 & 1 & $(2 \%)$ \\
$(6 \%)$ & $(10 \%)$ & $(3 \%)$ & $(8 \%)$ \\
\hline CHF & 0 & 1 & 1 & 0 & 1 \\
$(2 \%)$ & $(3 \%)$ & 1 & $(2 \%)$ \\
\hline Smoking & 4 & 14 & 17 & 1 & $18(36 \%)$ \\
$(8 \%)$ & $(28 \%)$ & $(56 \%)$ & $(3 \%)$ & 1 \\
\hline $\begin{array}{c}\text { Immune } \\
\text { suppressed }\end{array}$ & $\begin{array}{c}1 \\
(2 \%)\end{array}$ & 0 & $\begin{array}{c}1 \\
(3 \%)\end{array}$ & 0 & $\begin{array}{c}1 \\
(2 \%)\end{array}$ \\
\hline $\begin{array}{c}\text { Tuber- } \\
\text { culosis }\end{array}$ & $\begin{array}{c}1 \\
(2 \%)\end{array}$ & $\begin{array}{c}3 \\
(6 \%)\end{array}$ & $\begin{array}{c}2 \\
(6 \%)\end{array}$ & $\begin{array}{c}2 \\
(6 \%)\end{array}$ & $\begin{array}{c}4 \\
(8 \%)\end{array}$ \\
\hline \multicolumn{6}{|c|}{ Table 4. Distribution of Risk Factors According to } \\
\hline
\end{tabular}

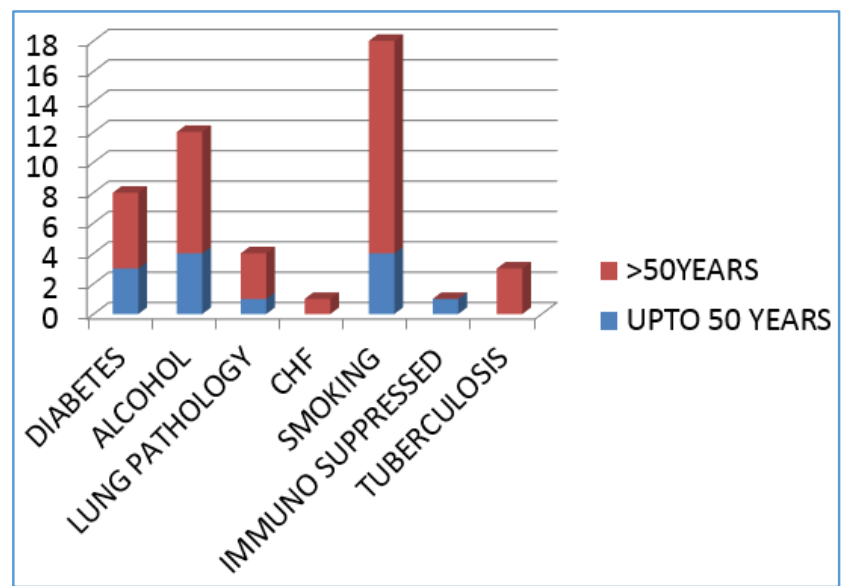

Figure 4. Distribution of Risk Factors According to Age

\begin{tabular}{|c|c|}
\hline On X-ray (Consolidation) & No. of Cases $(n=50)$ \\
\hline Right single lobe & $23(46 \%)$ \\
\hline Right two lobes & $5(10 \%)$ \\
\hline Left single lobe & $14(28 \%)$ \\
\hline Left two lobes & 0 \\
\hline Bilateral lower lobe & $8(16 \%)$ \\
\hline Total & 50 \\
\hline \multicolumn{2}{|c|}{$\begin{array}{l}\text { Table 5. Distribution of Cases According to } \\
\text { Radiological Findings }\end{array}$} \\
\hline
\end{tabular}

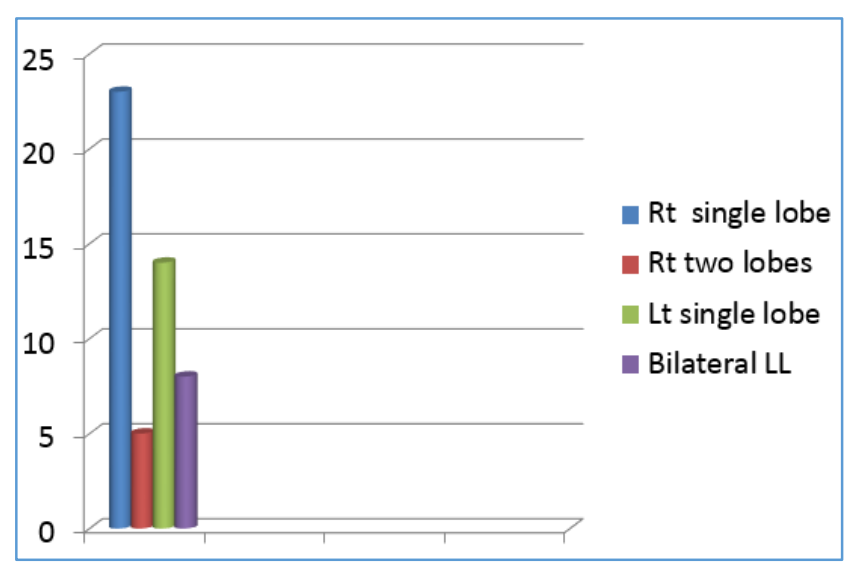

Figure 5. Distribution of Cases According to Radiological Findings

In the present study, the radiological finding (consolidation) was more common on right side constituting about $56 \%$ of the cases followed by left side (28\%) and bilateral involvement in 16\% cases. (Table 5).

On right side, upper lobe consolidation was seen in $8 \%$, middle lobe in $6 \%$, lower lobe was seen in $32 \%$, middle and lower lobe was seen in $10 \%$ of cases. On left side, lingular involvement was seen in $2 \%$, lower lobe consolidation was seen in $26 \%$ of cases. No involvement of left upper lobe was noticed.

Right lower lobe involvement is more common in this study which is closely related to the study conducted by R. S. Pushpa Kumari, V. A. Vipula, Jain $S^{6}$ who found right lower lobe consolidation was more common constituting about $26 \%$ of the cases.

\begin{tabular}{|c|c|c|c|}
\hline Complication & $\begin{array}{c}\text { Age }<50 \\
\text { years }\end{array}$ & $\begin{array}{c}>50 \\
\text { years }\end{array}$ & \begin{tabular}{|c|}
$\begin{array}{l}\text { No. of Cases } \\
(50)\end{array}$ \\
\end{tabular} \\
\hline Pleural effusion & 3 & 0 & $3(6 \%)$ \\
\hline Septic shock & 1 & 1 & $2(4 \%)$ \\
\hline ARDS & 0 & 2 & $2(4 \%)$ \\
\hline AKI & 0 & 3 & $3(6 \%)$ \\
\hline
\end{tabular}

Table 6. Distribution of Complications According to Age

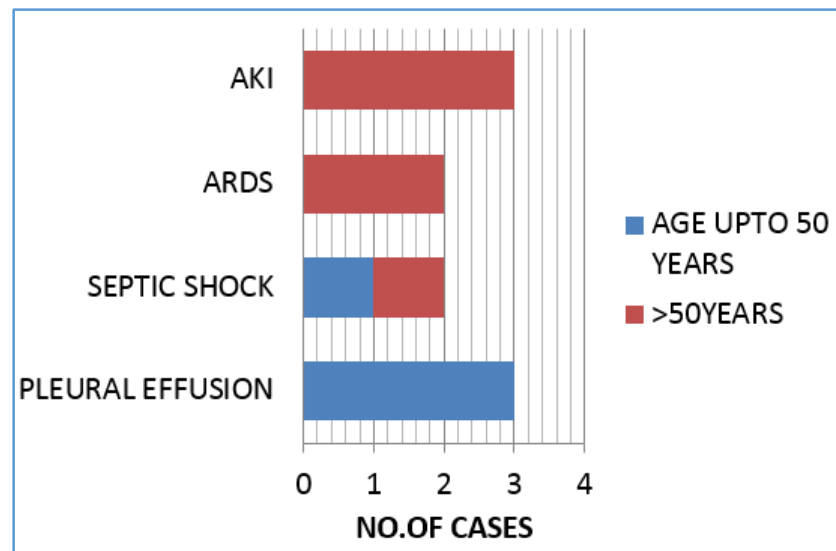

Figure 6. Distribution of Complications According to Age

The Table 6 shows patients $>50$ years developed more severe complications like ARDS and AKI. Septic shock affected both age groups equally and pleural effusion in $<50$ yrs. $20 \%$ of cases developed various complications.

\begin{tabular}{|c|c|c|}
\hline $\begin{array}{c}\text { Duration } \\
\text { of stay }\end{array}$ & $\begin{array}{c}\text { No. of Patients } \\
(\mathbf{n = 4 8} \text { ) Recovered }\end{array}$ & $\begin{array}{c}\text { No. of Patients } \\
(\mathbf{n = 2}) \text { Expired }\end{array}$ \\
\hline 1-7 days & $30(60 \%)$ & $2(4 \%)$ \\
\hline $8-10$ days & $12(24 \%)$ & 0 \\
\hline$>10$ days & $6(12 \%)$ & 0 \\
\hline \multicolumn{2}{|c|}{ Table 7. Duration of Hospital Stay } \\
\hline
\end{tabular}

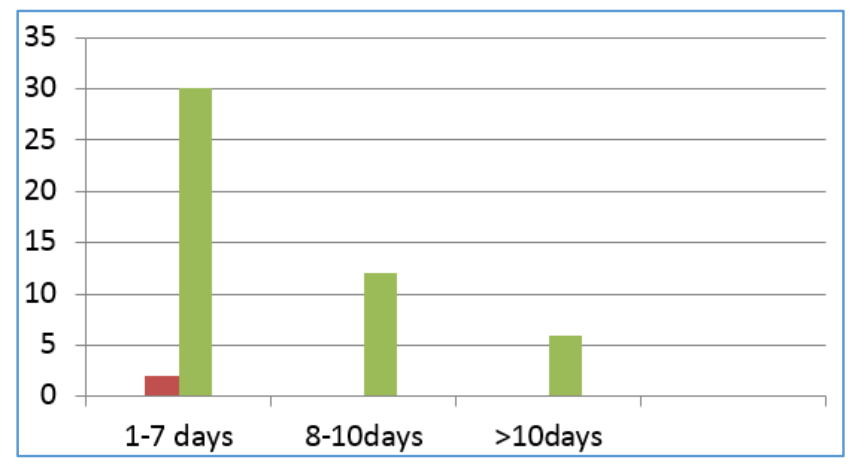

Figure 7. Duration of Hospital Stay

Table 7 shows most of the patients $(60 \%)$ recovered within a week and $24 \%$ cases recovered in 10 days and $12 \%$ cases recovered after 10 days. Mortality (4\%) occurred within 3 days of admission into the hospital. 


\begin{tabular}{|c|c|}
\hline Outcome & No. of Cases (n=50) \\
\hline Recovery & $48(96 \%)$ \\
\hline Death & $2(4 \%)$ \\
\hline Total & 50 \\
\hline \multicolumn{2}{|c|}{ Table 8. Outcome } \\
\hline
\end{tabular}

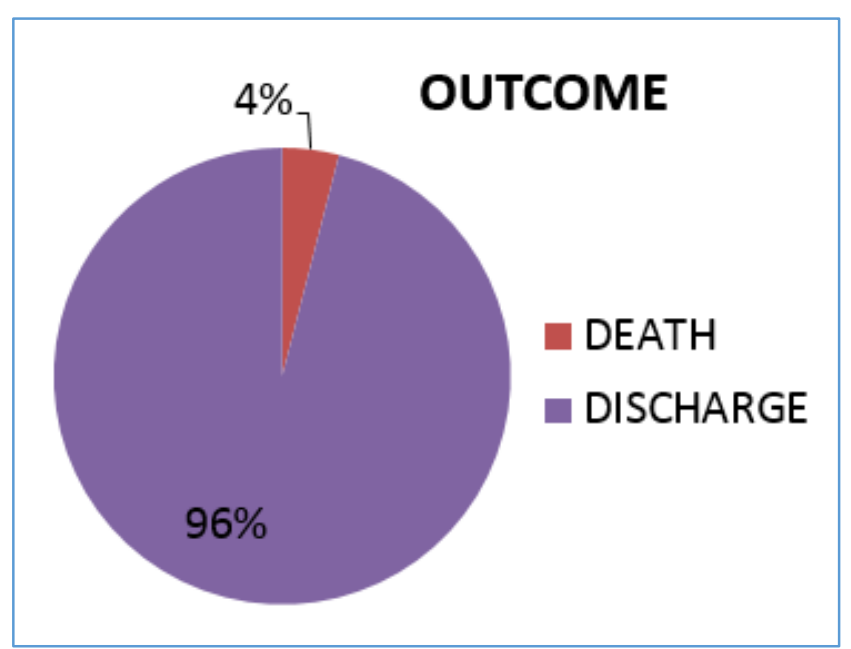

Figure 8. Outcome

In this study, 2 out of $50(4 \%)$ have mortality due to multiple risk factors (alcohol, smoking), age more than 50 years and complicated with ARDS, AKI and pleural effusion.

\section{DISCUSSION}

In recent years, both the epidemiology and treatment of pneumonia have undergone changes. Pneumonia is increasingly common among older patients and those with comorbidity like COPD, DM, renal failure, congestive heart failure, CLD and other conditions. ${ }^{7}$

In this study, less incidence was seen in age above 50 years (23\%) than up to 50 years $(27 \%)$ indicating the increased risk of susceptibility in young people. Further, $26 \%$ cases are in the age group of 51-60 years which shows that this age group is more vulnerable to lower respiratory tract infections like CAP. Less than 50 years group presented with cough with expectoration and above 50 years group with fever which shows rapid disease progression in the former. In this study, the incidence of Pneumonia was more common in males (60\%). Anatomic, lifestyle, behavioural and socioeconomic differences between males and females may explain the observed findings. ${ }^{8}$ Chest x-ray findings generally cannot distinguish one type of infection from another, although multilobar infiltrates suggest S. pneumoniae or Legionella pneumophila infection and Cavitating pneumonia suggests S. aureus or a fungal or mycobacterial aetiology. Right lower lobe involvement is more common (32\%) in this study.

Early response to treatment ( $>3$ days) results in reducing duration of hospital stay to a week, late response to 10 days. No response or development of complications leads to more than 10 days hospitalisation. Complications like ARDS, AKI are seen in older age which results in intensive care management and guarded prognosis. In addition to the infection, septic shock is generally thought to be caused by an excessive or uncontrolled pro-inflammatory response. ${ }^{9}$ In this present study, mortality (4\%) occurred within 7 days in male patients who developed complications. Advanced age increases the mortality from pneumonia.

In this present study, smoking (56\%) is the most common risk factor in both age groups ( 50 or less \& above 50 years). A study conducted in North-India revealed smoking as the most common risk factor for CAP (as high as 65\%). ${ }^{10}$ The main mechanisms for this predisposition relate to the suppressive effect that smoking has on the protective actions of the airway mucociliary clearance mechanism, on the various components of the innate and adaptive immune systems of the host, as well as direct effects on microbial pathogens that promote their virulence, and possibly antibiotic resistance. ${ }^{11}$ Alcohol is the second most common (24\%) risk factor in the study. A study by Koivula et $\mathrm{al}^{12}$ demonstrated a very important independent effect of alcoholism. Alcohol increases incidence of CAP by multiple mechanisms like increased risk of aspiration of gastric acid and/or microbes from oropharyngeal flora, decreased mucous-facilitated clearance of bacterial pathogens from the upper airway, and impaired pulmonary host defences.

It has been reported that old age and COPD impair pulmonary defences and predispose to CAP caused by Gramnegative bacteria. Similar types of findings were also reported from Indian studies. ${ }^{13}$

Identification and determining the clinical patterns and risk factors of Pneumonia (CAP) helps in adoption of regionally optimised diagnostic and therapeutic approach.

\section{CONCLUSION}

In Summary, the following points are observed-

1. Commonly affected age group is 51-60 years.

2. CAP is more common in males than females

3. Smoking is the commonest risk factor.

4. The incidence is influenced by the geographic region, patients' age, and presence of the predisposing factors.

5. Complications are common in more than 50 years of age.

6. The risk factors of CAP are both fixed and modifiable. Modifiable risk factors are those factors that are influenced by lifestyle or behavioural changes like heart disease, diabetes, smoking, alcohol. Non-modifiable risk factors are those we cannot control. They include age and gender. Modifiable risk factors should be strictly corrected especially in those who also have fixed risk factors.

7. Patients, particularly elderly and debilitated having risk factors, should be instructed to seek prompt medical care during the early stages of dyspnoea or fever to prevent complications.

\section{REFERENCES}

[1] Epidemiology of community-acquired pneumonia. Supplement to Journal of the Association of Physicians of India 2013;61:7-8.

[2] Pneumonia Causes-Mayo Clinic. www.mayoclinic.org. Retrieved 2015-05-18.

[3] Woodhead MA, Macfarlane JT, McCracken JS, et al. Prospective study of the aetiology and outcome of pneumonia in the community. Lancet 1987;1(8534):671-4. 
[4] Who is at risk for pneumonia? NHLBI 1 March 2011. Archived from the original on 7 March 2016. Retrieved 3 March 2016. Brown JS. Community-acquired pneumonia. Clin Med (Lond) 2012;12(6):538-43.

[5] Welte T, Torres A, Nathwani D. Clinical and economic burden of community-acquired pneumonia among adults in Europe. Thorax 2012;67(1):71-9.

[6] Kumari RSP, Vipula VA, Jain S. Clinical, radiological and bacteriological profile of patients with community acquired pneumonia (CAP). IAIM 2016;3(6):59-64.

[7] Marrie TJ, Durrant H, Yastes L. Community acquired pneumonia requiring hospitalization: 5-year prospective study. Rev Infect Dis 1989;11(4):586-99.

[8] Falagas ME, Mourtzoukou EG, Vardakas KZ. Sex differences in the incidence and severity of respiratory tract infections. Respir Med 2007;101(9):1845-63.
[9] Annane D, Bellissant E, Cavaillon JM. Septic shock. Lancet 2005;365(9453):63-78.

[10] Shah BA, Singh G, Naik MA, et al. Bacteriological and clinical profile of community acquired pneumonia in hospitalized patients. Lung India 2010;27(2):54-7.

[11] Feldman C, Anderson R. Cigarette smoking and mechanisms of susceptibility to infections of the respiratory tract and other organ systems. J Infect 2013;67(3):169-84.

[12] Koivula I, Sten M, Mäkelä PH. Risk factors for pneumonia in the elderly. Am J Med 1994;96(4):313-20.

[13] Pifarre R, Falguera M, Vicente-de-Vera C, et al. Characteristics of community-acquired pneumonia in patients with chronic obstructive pulmonary disease. Respir Med 2007;101(10):2139-44. 